\author{
Kushnir Anton \\ art history $\mathrm{PhD}$, associate professor at the \\ Department of woodwind instruments, \\ Petro Tchaikovsky National Music \\ Academy of Ukraine \\ https://orcid.org/0000-0002-3264-683X \\ kushnirantonflute@gmail.com
}

\title{
KYIV FLUTE PERFORMANCE SCHOOL: MAIN PRINCIPALS
}

The purpose of this article is to learn and present the technical components of the Kyiv flute performance school. The research methodology is based on the interrelation between the historical-descriptive and the inductive methods. Some provisions are based on the results of generalization of empirical observations, as well as the author's own performing and pedagogical experience. The scientific novelty of the research focuses on the necessity to systemize the pieces of history about Kyiv's flute school and the work of its alumni and study their theoretical principals in the vast context of international performance traditions. Conclusion. A well based performance apparatus is about dynamic formation. Its components are in complex interrelation. The everlasting process of achieving their perfection and reciprocity in harmony demands durable, conscious and theoretically founded work. Focus on this process is provided by the traditions and originality of the performance schools, and constancy and consistency of the practice of their leading representatives.

Keywords: flute; position; music performance; Kyiv music traditions.

Кушнір Антон Ярославович кандидат мистецтвознавства, доцент кафедри дерев'яних духових інструментів Національної музичної академії України імені П. І. Чайковського

Київська флейтова виконавська школа: базові засади

Мета статті полягає у розкритті технологічних складових виконавського аспекту Київської фрлейтової школи. Методологія дослідження базується на взаємозв'язку таких методів як історико-описовий та індуктивний. Ряд положень ґрунтується на результатах узагальнення емпіричних спостережень, а також власному виконавському та педагогічному досвіді автора статті. Наукову новизну роботи обумовила необхідність систематизації уривчастих відомостей про історію Київської фрлейтової школи та творчий доробок її представників, дослідження теоретичних принципів у контексті світових виконавських традицій. Висновки. Вірно поставлений виконавський апарат є динамічним утворенням, компоненти якого знаходяться між собою у складній залежності. Безперервний процес досягнення їх абсолютної, гармонійної взаємодії потребує тривалої, осмисленої, теоретично обґрунтованої роботи. Спрямованість цього процесу забезпечують традиції та самобутність виконавських шкіл, сталість та системність діяльності їх провідних представників.

Ключові слова: флейта; постановка; музичне виконавство; Київські музичні традиції.

Кушнир Антон Ярославович, кандидат искусствоведения, доцент кафредры деревянных духовых инструментов Национальной музыкальной академии Украины имени П. И. Чайковского

Киевская флейтовая исполнительская школа: основные принципы

Цель статьи заключается в раскрытии технологических составляющих исполнительского аспекта Киевской флейтового школы. Методология исследования базируется на взаимосвязи таких методов как историкоописательный и индуктивный. Ряд положений основывается на результатах обобщения эмпирических наблюдений, а также собственном исполнительском и педагогическом опыте автора статьи. Научную новизну работы обусловила необходимость систематизации отрывочных сведений об истории Киевской флейтового школы и творчестве ее представителей, исследование их теоретических принципов в контексте мировых исполнительских традиций. Выводы. Правильно поставленный исполнительский аппарат является динамичным образованием, компоненты которого находятся между собой в сложной зависимости. Непрерывный процесс достижения их абсолютного, гармоничного взаимодействия требует длительной, осмысленной, теоретически обоснованной работы. Направленность этого процесса обеспечивают традиции и самобытность исполнительских школ, постоянство и системность деятельности их ведущих представителей.

Ключевые слова: фрлейта; постановка; музыкальное исполнительство; Киевские музыкальные традиции.

Relevance of the study. History and modernity of Ukraine's musical arts in the present time are being productively researched by many scholars. The study of national music and its performance, study of the specificity of pedagogical methods in performance are the present goals of contemporary national arts research.

The attempts to find the specificity and character of Ukraine's national and regional schools of wind instruments become more and more coherent. Analysis of research and publication reveals that in present time the main subject of dissertation researches are Lviv Flute Performance School (A. Karpyak, "The Art of Flute in Lviv Musical Culture") Kyiv's and Ukraine's School of Trumpet (V. Posvalyuk, "The becoming of Ukraine's School of Trumpet Performance and its development problems: History, Professional Performance, Theoretical and Methodical Aspects") etc. 
The early history of Ukraine's professional wind performance was studied by P. Krul, "National wind instruments arts of Ukraine's people (the least studied pages of history)". The German flute tradition that has influenced Ukraine were researched by V. Kachmarchyk, "German Flute Art of the $18^{\text {th }}$ and $19^{\text {th }}$ centuries". The work of the founder of the studied school, A. Protsenko, and his surrounding is described thanks to the publication of a collection of articles "Andriy Protsenko: Life Description. Reminiscence", edited by I. Gamkalo and L. Protsenko [1]. Important information about history of wind instruments performance and especially Kyiv flute school is presented in V. Bogdanov and Yu. Rudchuk publications. The cultural aspects of Ukraine's flute arts are being discussed in Yu. Shutko ("Flute arts of the $20^{\text {th }}$ century in the context of Ukraine's culture").

The goals of this article are parallel to the contemporary interest in studying historical, theoretical, methodical and practical questions in a specific musical specialization. It aims at discovering technical components of the practical performance aspect of Kyiv's flute school- the center of Ukraine's flute art. The vast versatility of creation of its alumni allows to name it as a systematic creative and artistic flow in the national music arts. Nevertheless, for long time, flute performance in our country and its main components were studied only in the context of general development of Soviet wind instruments performance, apart from international trends. Moreover, only some pieces and notes about the history of Kyiv flute performance school, the work of its representatives and their theoretical principals were accessible. It was indeed necessary to systemize this data, hence the innovation of this article.

Statement of basic materials. Researches of wind instruments schools note the study of specificity of performance and expressive means. Especially they note the solutions to methodical questions (methodical aspect). The discovery of the performance aspect of Kyiv's flute school is about studying the performance theory (the variety of components of performance technique, performance and expressive means) and specificity of practical application of theoretical material.

Undoubtedly, it is important to define the main principals in obtaining performative skills, that happened as a result of applying methodic; complex of specific, tested and studied rules and methods of instruction. Common, distinctive features of application of expressive means by professional musicians that represent certain schools are reflections of the performing specificity of the given school, of performing tradition.

Technical components of flute performance art. The performance instrument of the wind group is different from other musical instruments by many physical components. That is why so much attention is being dedicated to the standing position and questions of technical order from very early stages of practice and all the next levels. The meaning of "position" is defined by "collection of rules that regulate the position of the corpus, head, legs, arms, and fingers interrelating with each other and with the instrument", notes B. Dikov $[3,67]$. R. Teryokhin, in his turn, states: "With the correct position we understand the most rational adjustment of the performer's body to the instrument" [6, 17]. Likewise, definitions are to be found in V. Apatsky, "Position - a pose of adjustment of the corpus to play a wind instrument. The static position has a negative influence on the instrument. The way to fixation in straight, and from fixation to contraction. The instrument has to be free and alive..." $[2,44]$.

S. Savchenko, a student of A. Protsenko, recalls the saying of professors to whom he has explained his opinion towards this question: "...We have to make it comfortable not only for you, Protsenko said to one of his students, but first of all it has to be comfortable for the flute" [1, 174]. Protsenko's, V. Pshenychny's and A. Kogan's students also note that undoubtedly significant time was dedicated to the question of aesthetics and rationality of position of the instrument $[1,168]$. "I recognize my own students by their position" noted A. Protsenko [1, 103].

Protsenko's followers stood by his pedagogic views. Ya. Verhovinez, who dedicated many of his years working with young ages, recalls that professor Protsenko has dedicated a great part of his time to "correcting different flaws in the student's professional position and skills and sometimes some of the student's incorrect ideas and musical perception" [1, 142].

A student of A. Protsenko and G. Strokach, leaning on the view of her professor, says: "the position is the main part in the process of learning the flute" $[1,89]$. There are some rational rules about the position of the flute itself, but we must note that every performer is physically different. That determines the specificity of the adjustment to the wind instrument while playing. The goal of formation and perfection of the position is obvious - achieving high performance results with minimal physical effort.

A narrow definition of position is used to characterize the process of obtaining some professional, musical expressive and performance means of component of the wind instrument (breathing, lips technique, tongue, fingers etc). Only balanced and exact combination of the mentioned above can provide a professional mastering of the instrument. V. Ivanov defines the posture as "a process of reciprocity of all components of the corpus and the instrument", at the same time as one of the components of technique [4, 77]. At his class $\mathrm{V}$. Antonov taught the combination of absolute freedom, minimization and precision, aesthetics of body language while playing the flute.

V. Apatsky clarifies the specificity of position, schematically reflecting the specificity of each wind instrument, especially the flute $[2,57]$. The transverse flute must be held horizontally, though some deviations are possible. The most important detail is to keep the head of the flutist naturally while playing-perpendicular to the torso, and the elbow of the right hand is not pressed towards the torso. In Johann Joachim Quantz we 
find: "The head must always stay in a position turning upwards, but natural, not complicating the rout of the air...the incline of the head may become not only the reason to an incorrect position, but damage the playing itself. The throat is jamming and that leads to difficulties while breathing".

Expressive and performative means. The definition of posture and position and technique in wind instrument are very close. Technique (from Greek - Techne - art, craft) in the musical performing arts is a combination of crafts and features of the player, the development of which may be an indication of the player's level. These features are correct posture, harmonically development of breathing, fingers and ways of fingering, tongue and lips (articulation).

Not only the articulation, but specific movement of the lips affect the coloring of the flutist sound. In an active situation (playing), together with the pulsating state of the larynx, vast open condition of the oral cavity, according to $\mathrm{V}$. Antonov, they are another performing mean - the apparatus that form the color and quality of sound [5]. We must note that the musical hearing refers to that category of means ("performing biophysical means of the wind instrument player") as well [4, 97].

To the "expressive means", the reproduction of which depends on the result of the technical means, we may add the quality of sound (according to B. Asafiev, modification of the color and quality is the expressiveness, V. Antonov used the term "color formation" [5]), the intonation of sound, vibrato, dynamics (a means on its own, benefits the performance on brass instruments, called filigree), touches, phrasing. To that group there are traditionally referred such auxiliary means as rhythm, meter, tempo.

The highest level of expression is about breathing. The performers breathing affects the development of sound, its quality, and the articulation of the mouth. The optimal breathing for wind instruments, especially the flute, is chest-abdominal (mixed) breathing. An important element in the performer's technique during exhalation is interrelation between breathing base and sound coloring features that provide the creation of sound quality in playing (coloring, sound range, intonation, dynamics and more). Finally, it forms individual quality of sounding - the tone.

Conclusions. A well based performance apparatus is dynamic formation. Its components are in complex interrelation. The everlasting process of achieving their perfection and reciprocity in harmony demands durable, conscious and theoretically founded work. Focus on this process is provided by the traditions and originality of the performance schools, and constancy and consistency of the practice of their leading representatives. Using the mentioned above performing, expressive means lead to the final goal of music interpretation - the discovery of the artistic feature and the content of the musical piece. "The creation of a full artistic image is based on perfect technical skills of the performer. Only with perfect technique a dialogue with the public on the level of high artistic categories is possible", - stated A. Protsenko [1, 154-155].

\section{תimepamypa}

1. Андрей Проценко: Жизнеописание. Воспоминания / [Сост. и коммент.: И. Д. Гамкало, Л. А. Проценко]. М. : Музыкальная Украина, 1990. 286 с.

2. Апатский В.Н. Основы теории методики духового музыкально-исполнительского искусства. М. : НМАУ им. Чайковского, 2006. 432 с.

3. Диков Б. А. Методика обучения игре на духовых инструментах. М. : Музгиз, 1962. 116 с.

4. Иванов В. Д. Словарь музыканта-духовика. М. : Музыка, 2007. 128 с.

5. Кушнир А.Я. Профессор В.С. Антонов: специфика педагогических принципов / Режим доступа: http://uasol.com/index.php?aid=3355

6. Терехин Р. П., Апатский В. Н. Методика обучения игре на фаготе. М. : Музыка, 1988. 208 с.

7. Quantz J. J. Versuch einer Anweisung, die Flöte traversiere zu spilen. Reprint der Ausgabe Berlin, 1752. Mit einem Vorwort von H.-P. Schmitz. Mit einem Nachwort, Bemerkungen, Ergänzungen und Registern von H. Augsbach. 4 Auflage. Kassel: Bärenreiter-Verlag. Karl Vötterle GmbH \& Co. KG, 2004. 424 S.

\section{References}

1. Andrey Protsenko: Life Description. Reminiscence/ [Edited by: I. D. Gamkalo, L. A. Protsenko]. M. : Musial Ukraine, 1990. 286 p. [in Russian].

2. Apatsky V. N., Main question in theory of methodic of wind instruments performance. M. : Petro Tchaikovsky National Music Academy of Ukraine. 2006. 432 p. [in Russian].

3. Dikov B. A., Methodic of teaching the wind instruments. M. : Muzgiz, 1962. 116 p. [in Russian].

4. Ivanov V. D., Musical wind instrumental dictionary. M. : Music, 2007. 128 p. [in Russian].

5. Kushnir A. Ya., Prof. V.S. Antonov: Specifics of pedagogical principals. Link: http://uasol.com/index.php?aid=3355 [in Russian].

6. Teryokhin R. P., Apatsky V. N., Methodic of teaching the bassoon. M. : Music. 1988. - 208 p. [in Russian]

7. Quantz J. J. VersucheinerAnweisung, die Flötetraversierezuspilen. Reprint der Ausgabe Berlin, 1752. MiteinemVorwort von H.-P. Schmitz. MiteinemNachwort, Bemerkungen, Ergänzungen und Registern von H. Augsbach. 4 Auflage. Kassel: Bärenreiter-Verlag. Karl Vötterle GmbH \& Co. KG, 2004. 424 S. 